\title{
機能的人工歯使用経験 2 例
}

大 場 栏 照*

\section{Case-reports used Non-anatomic Teeth}

Yoshiteru. Ohba

\section{1. まえがき}

機能的人工歯 (Non-anatomic teeth) の歴史は相当古 $\left.\left(か^{6}\right), 16\right)$, 解部的人工歯 (Anatomic teeth) との優劣に ついての論争は, 現在までもつついている4),13).

わが国では，一般に機能的人工歯は使われていない が，その優れている点とされているのは，次の諸項であ る.

\section{a. 推進運動}

全部床義歯の推進運動は，第 1 に校合小面の傾斜角が ある限り, 避けられない，すなわち，咀嚼運動が臼磨運

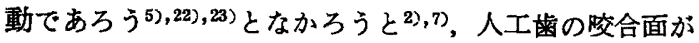
傾斜角をもつているかきり上下人工歯間の食物の介在に よつて, 推進運動が起される.

この点を教科書加ら引用すると（図 1, 図2, 図 3） のようである.

第 2 には, 上下人工歯の不適当な排列でも起る9),18). この推進運動の結果と思われる症例を図示すれば（図 4 図 5,図6）の如くである.

結論として上記第 1 , 第 2 の点は根本的には同じこと である. 特に第 2 の点は機能的人工歯でも，解剖的人工 歯でも起る問題であるから除外してみても，解剖的人工 歯を使用した場合にさけられない問題は, 義歯を水平に “ゆさぶる運動”である.これは顎提の吸收変形, 軟化 あるいは疼痛の原因となる8，199．このことは機能的人工 趋使用の第 1 番目の理由である.

\section{b. 咬合採得之咬合器}

中心睖合位にせよ，顆路の傾斜角にせよ，その詳細を 松合器に再現して, 完全無欠な義歯を装着させることは 現在のところほとんど不可能に近い. 何故なら咬合器の


Roberts ${ }^{13)}$ は咬合採得の困難3)さをたとえて，“ろぶね”

*.名古屋市中村区広井町 3 の98名古屋ビル 5 階
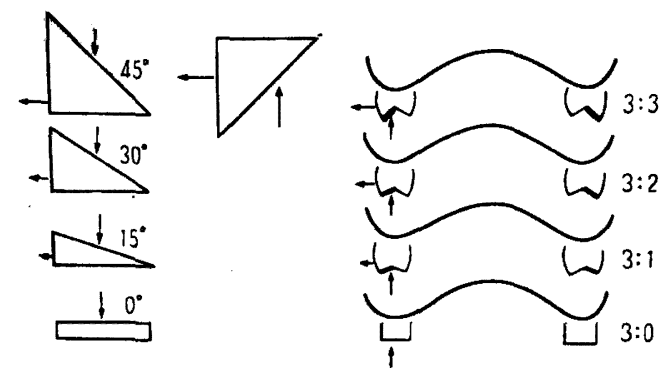

图 1 Nagle-Sears ${ }^{11}$

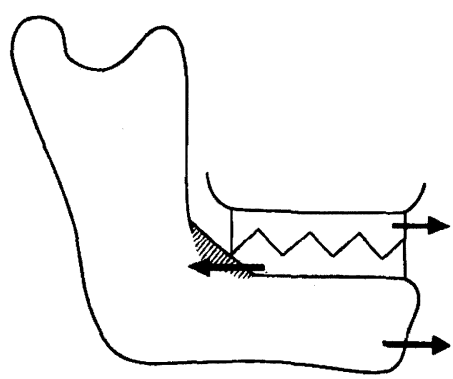

图 2 Nagle-Sears ${ }^{11}$

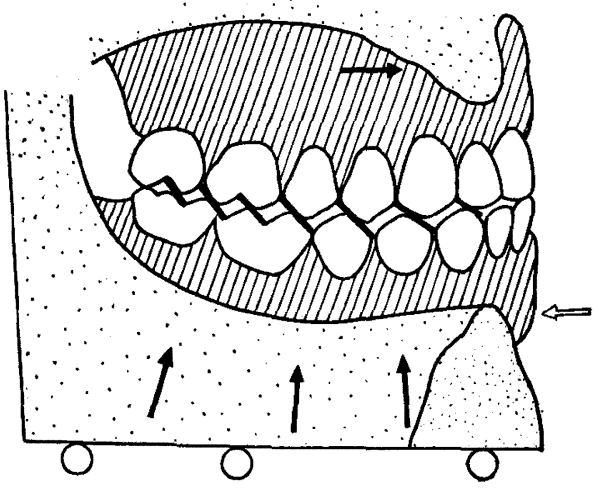

図 3 中沉 24

の上で六分儀を报うのに等しいと表現しているのであ 


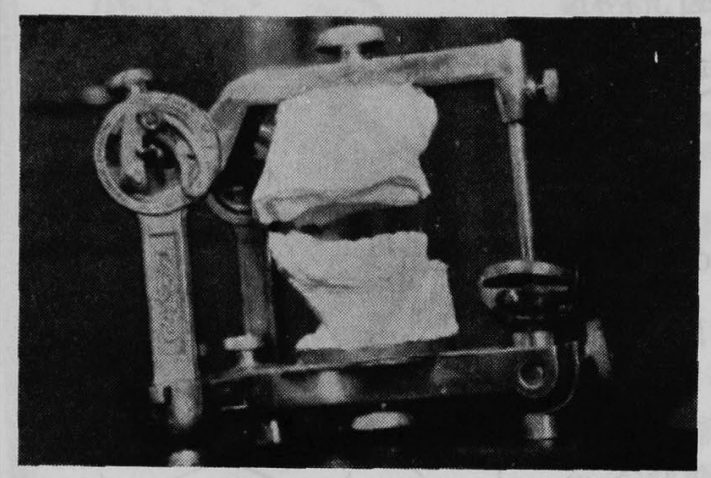

图47、に対して顎に堤を無視して $\mid 7$ を排列 したために上碞前歯部がこんにやく様顎堤 になつた例

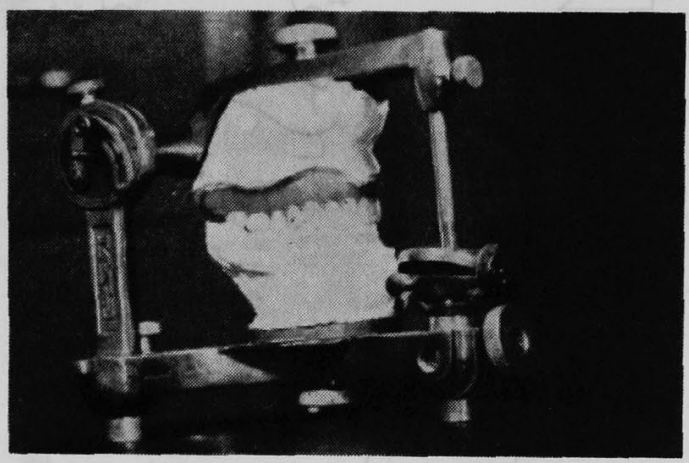

図 5 前図（図 4）上の義歯

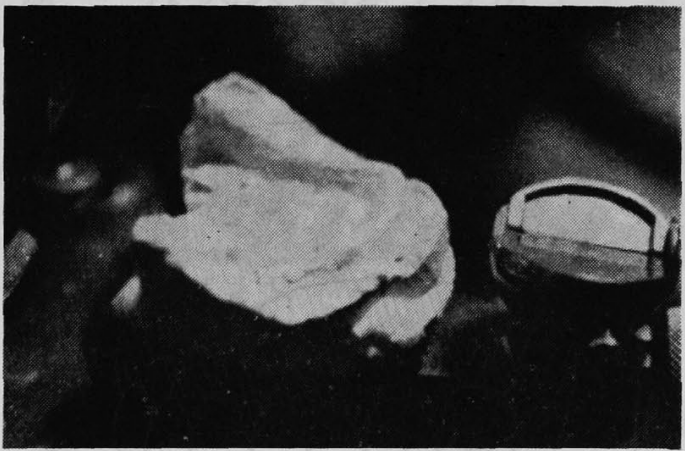

図 6 下顎々堤上行部に $\sqrt{7}$ を排列したために 起つた前歯部䪽堤の变形，すなわち唇側に 傾科した例

る、このような困難さ，云いかえれぱ不正確さを代償さ せる12)意味でも機能的人工歯を使用する理由が生まれて くる.こ〉で特に注意しなければならないのは，呚合採 得および胑合器から必然的にくる多少の不正確さは, 顥 関節が適合してくれるだろうという甘い考えであつて， Searsは、はつきりと次のようにいつている。すなわち,


関節の平衡を畨牙の陵合平衡に導かしてはならない。

\section{c. 咀哷能率の問題}

従来機能的人工歯の欠点とされていた咀噢能率が低い ということも，最近の研究100,20)によれは，必らずしも 決定的なものではない.

\section{d. クリステンゼン現象}

機能的人工歯使用にあたつて考えられる最大の問題は 上下義歯の離開の問題である. しかし前後・左右運動によ つて生ずるクリステンゼン現集に対しては, Landy9 Balancing Ramp, Nagle-Searsi1) 等の Balancing Occlusal unit などの名称で床に附属させる装置によつて 充分代償出来る. したがつて機能的人工歯の使用を否定 する理由にはならない。

\section{e. その他の問題}

Boos $^{1)}$ の主張する機能的人工歯の使用根拠は次のよう である．歯ぎしり運動に近いような咀嚼運動をする患 者, すなわち彼のいう機能的範囲の大きい患者ではて の機能的範囲に調和させるた炕，人工歯は削合によつ て結局咬頭傾科の少い平らな咬合面になるか，あるいは 非解剖学的形態の mechanical typeになるからである。

さらに, Sears ${ }^{15)}$ は顆頭の偏位吕無歯顥患者にしばし ば現われることを指摘し、この現象は機能的人工歯の使 用によつて容易に治療出来ると述べている.

以上のように考えてくると，機能的人工歯が解剖的人 工歯に劣るということはなく，かえつて優れているとさ え結論ずけられるのである。

私は最近機能的人工歯を使用することによつて成功し た症例を経験したのでここに報告する次第である.

\section{2. 症，例}

症 侧 1 上下影無遏症 168 才

既 往 歴: 初䛦時には上顎は無歯顎, 下顥は $\overline{321 \mid 145}$ 残存で何れも歯槽膿漏であつて拔歯の適庆症であつた。 そこで義歯製作の前準備として抜歯した。

施 術: 拔歯1 カ月後，通法に從い印象採得をおこな つた．咬合採得に当つては，右側・側方陵合の悪習慣が あり中心㬵合位の決定がほとんど不可能であつた。 中心 㥖合位の採得には教科書 ${ }^{24), 25)}$ に見られる通常の方法に よつても,また Gothic archの描記, 口外法 (Sears Trivet を使用)，あるいは口内法 (Coble Balancerを使 




図 7 定 例 1

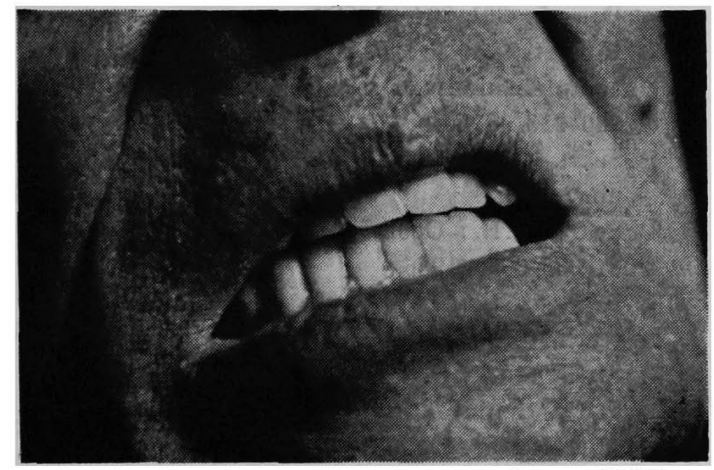

図 8 疪例 1 (義雪装着直後) 側方答合の悪習惯

用にによつても満足な結果は得られなかつた。ともかく ぞうやらこれと思われる位置を中心咬合位として解剖的 人工歯を使用した義爾を製作した。

結果および予後：義歯装着後，患者はいちおう满足し たが晈合の悪習慣はいぜんとして続き，ために咀嗠時の 外観が悪かつた（図 7,8). さらに前方咬合位にあた り，三点接触がくずれ，前畨だけが早期に珓合していわ ゆる早期接触を示した．約 1 カ月経過を観祭したが，や はり不正咬合は治癒せず不満足な結果が続いた，その結 果側方にはもちろん，上下的にも顆頭の偏位があるもの と診断した。

そこで中心咬合位の不正確を代敃させると同時に側方 および上下的の顆頭の偏位の治療の目的 ${ }^{14), 15) て ゙, ~ H a r d y ~}$ の機能的人工歯を使用した（図9). 製作方法は Landy ${ }^{91}$ ，Nagle-Sears ${ }^{11)}$ の手順に従つたが，特に上下 的な顆頭の偏位の対策は Landy の方法に從つた. 私の おこなつた方法で幾分異つている点は Balancing Ramp の作り方で，顆路を出来るだけ正雄に再現するために次 のように処理した．重合研磨された下顥義歯の第 1 大臼 㐘の直後すなわち第 2 大臼歯の位置に軟化したパラフイ ン・ワックスを盛り，1日患者の自由な晈合運動（この

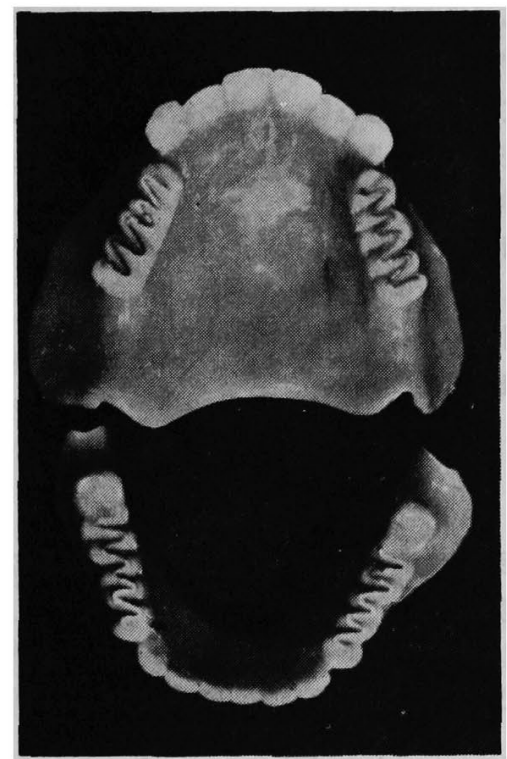

图 9 症例 1 Hardy の機能的人工歯使用 患者の顆路傾斜角は全く不安定であつたが，それでもい ちおう現われた角度は左 $25^{\circ}$ ，右 $10^{\circ}$ であつたので, 大 体左 $30^{\circ}$ 右 $15^{\circ}$ 位の角度にパラフィン・ワックスを盛 つたをさせ傾斜角を印象した。これを即時重合レジン でおきかえた，なおこのさい傾斜角の印象が食片で傷 つけられないように食物の種類に注意を与えた。

経過は非常に良好で過蓋珓合は咬合器上とまつたく同 じ位置におちついた，後処置の必要もなく経過し，2 週 間で不正咬合・側方恔合の悪習慣も治癒した。

症 例 2 上下頡無䨑症 合 73 才

既 往 歴: 解剖的人工歯を使用した義蒾を装着してい た、空口運動ではまつたく疼痛はなかつたが, $\sqrt{45}$ 部 は咀嚼運動時に疼痛を生ずる症例であつた（因10），同 部の疼痛は床の不適合とも考えられず，人工歯の不正排

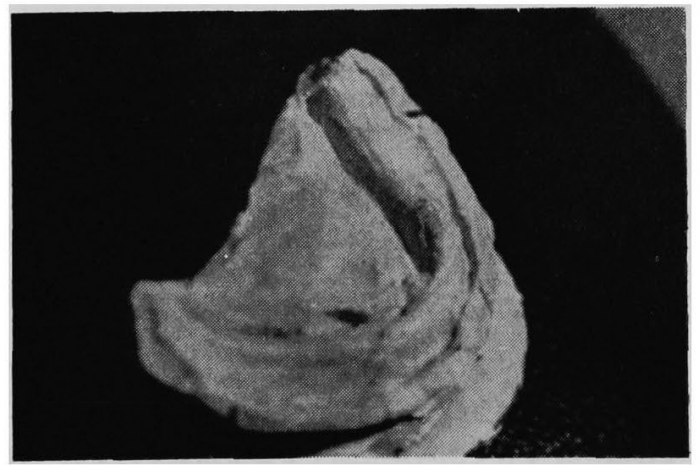

因 9 症例 2 疼痛部 
列による推進運動とも思われない. $\sqrt{45}$ 部には潰喀も 見られず，強いて変つた状態といえぼ，その部分が多少 軟化しているに過きない，診查の結果この部分は咬合小 面の存在に起因する僅かの推進運動が作用しておこる疼 痛と推論した。

施 術：以上の診断の結果，本症例にも機能的人工歯 を使用した，本例の顆路傾斜角は，左右とも20。でこの 角度に対して（第 1 例）と同様の処理をした。

予 後: 良好であつた。

\section{3. 考 察}

（第 1 例）顆頭偏位が上下的にも側方的にも存在し た．機能的人工菌を使用することによつて容易に治瘾し た例と考える.

（第 2 例）咬合小面の存在で起る推進運動を機能的人 工崡の使用で排除し，疼痛除去に成诃した例と考える，

\section{4. 結論}

機能的人工歯を使用して成功した 2 例を報告した。こ のさい用いた Balancing Ramp は下顎運動を考虑して 設計されたもので, 非常に有効であつた。

最後に本小文を中沢教授に目を通して頂いたことは， 大変な幸いであつた。

\section{文献}

1) Boos, R.H.: Centric relation and functional areas, J. Pros. Den. 9; 191-196, 1959.

2) Boswell, J.V.: Practical occlusion in relation to complete dentures, J. Pros. Den. 1; 307, 1951.

3) Craddock, F.W.: The accuracy and practical value of records of condyle path inclination, J. Pros. Den. 38; 697-710, 1949.

4 ) Gehl, D.H. and Dresen: Complete denture prosthesis, 4ed. Philadelphia, 1959, W.B. Saunders Co., pp. 303-307.

5) Gysi, A.: Handbuh der Zahnheilkunde IV, Berlin, 1929, Urban \& Schwarzenberg, 1171.

6) Hardy, I. R.: The developments in the occlusal patterns of artificial teeth, J. Pros. Den. 1; 14-18, 1951.

7) Kurth, L. E.: Mandibular movements in mastication, J.A.D.A. 29; 1769-1790, 1942.

8) Kimball, H.D.: Factors to be considered in control and elimination of chronic tissue soreness beneath dentures, J. Pros. Den. 4; 298-311, 1954.

9) Landy, C.: Full dentures, St. Louis, 1958, C.V. Mosby Co. pp. 91-96.

10) Manly, R.S. and Vinton, P.: A survey of the chewing ability of denture wearers, J. D. Res. 30; 314, 1951.

11) Nagle, R. J. and Sears, V.H.: Dental prosthetics, St. Louis, 1958, C. V. Mosby Co. pp. 396-411.

12) Payne, S. H.: Selective occlusion, J. Pros. Den. 5; 301-304, 1955.

13) Roberts, A. L.: Present-day concepts in complete denture service, J. Pros. Den. 9; 900-913, 1959.

14) Sears, V.H.: Methods of measuring condyle migration.

15) Sears, V.H.: Occlusal pivots, J. Pros. Den. 6; 332-338, 1956.

16) Sears, V.H.: Thirty years of nonanatomic teeth, J. Pros. Den. 3: 596-617, 1953.

17) Shanahan, J.E.J. and Leff, A.: Mandibular and articulator movements, J. Pros. Den. 9; 941-945, 1959.

18) Sharry, J.J., Weber, I. and Parkel, C.: A study of the influence of occlusal planes on strains in the edentulous maxillae and mandible, J. Pros. Den. 6; 768-774, 1956.

19) Schwartz, M.M.: Some important considerations in tooth arrangement, J.A.D.A., 1929.

20) Trapozzano, V. R. and Lazzari, J. B.: An experimental study of the testing occlusal patterns on the same basis, J. Pros. Den. 2 ; 440-457, 1952.

21）石原寿郎：下顎運動について，歯科口㬵外科最 近の進歩 (第 1 集), 東京, 昭31 (1956), 医歯 薬出版株式会社 215-246 頁.

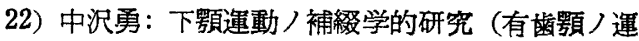
動), 口病誌, 13巻 2号, 81-96, 昭14 (1939).

23）中沢勇：下顥運動ノ補緅学的研究 (無鮆頡ノ運 動), 口病誌, 14巻 3号, 160-165頁, 昭15(1940).

24）中沢勇：補綴学総論 と全部床義歯の実際, 京都, 昭28 (1953), 永末書店, 105-106頁.

25）坪根政治：総義歯患者の昗合採得法，東京，昭 33 (1958)，医歯薬出版株式会社，59-67頁。 101-108頁. 